Original Article

\title{
DEVELOPMENT AND VALIDATION OF STABILITY INDICATING METHOD RP-HPLC METHOD OF ACOTIAMIDE
}

\author{
CHARU P. PANDYA, SADHANA J. RAJPUT*
}

Quality Assurance Laboratory, Centre of Relevance and Excellence in Novel Drug Delivery System, Faculty of Pharmacy, Shri G. H. Patel Pharmacy Building, The Maharaja Sayajirao University of Baroda, Fatehgunj, Vadodara, 390002, Gujarat, India

Email: sjrajput@gmail.com

Received: 22 Jan 2018 Revised and Accepted: 17 Jul 2018

\section{ABSTRACT}

Objective: The objective of present work was to develop and validate simple, precise, accurate and specific stability indicating method for determination of acotiamide in presence of its degradation products.

Methods: An isocratic RP-HPLC method has been developed using C-8 Thermo Hypersil BDS Column (250 x 4.6 mm i.d., $5 \mu$ particle size) with the mobile phase composition of acetonitrile: $0.1 \%$ triethylamine in $0.2 \%$ formic acid (30: 70) at column oven temperature of $40{ }^{\circ} \mathrm{C}$. The flow rate was $1.0 \mathrm{ml} \mathrm{min}^{-1}$ and effluent was detected at $282 \mathrm{~nm}$. The method was validated in terms of linearity, accuracy, precision, LOD (Limit of Detection), LOQ (Limit of Quantification) and robustness as per ICH guidelines.

Results: The method was found to be linear in the range of $10-60 \mu \mathrm{g} / \mathrm{ml}$. Limit of detection and limit of quantification was found to $0.36 \mu \mathrm{g} / \mathrm{ml}$ and $1.10 \mu \mathrm{g} / \mathrm{ml} . \%$ Recovery was found to be in the range of $99.45 \%-99.75 \%$ and precision less than $2 \%$. The developed method was successfully applied for estimation of Acotiamide in marketed tablet formulation and percentage assay was found to be $100.45 \%$. Acotiamide was subjected to stress degradation under acid, base, neutral hydrolysis, oxidation, dry heat, photolysis conditions. Significant degradation was observed in acid and base degradation.

Conclusion: The developed RP-HPLC method was simple, rapid, accurate, precise and stability indicating for the estimation of Acotiamide in bulk and tablet dosage form.

Keywords: Acotiamide, Reverse Phase High Performance Liquid Chromatography(RP HPLC), Stability Indicating Assay Methods (SIAM's), Stress Degradation, ICH Q1A(R2), Q2R1

(C) 2018 The Authors. Published by Innovare Academic Sciences Pvt Ltd. This is an open access article under the CC BY license (http://creativecommons.org/licenses/by/4.0/) DOI: http://dx.doi.org/10.22159/ijpps.2018v10i9.24925

\section{INTRODUCTION}

Acotiamide (ACOT) is N-[2-[di(propane-2-yl)amino]ethyl]-2-[(2hydroxy-4,5-dimethoxybenzoyl)amino]-1,3-thiazole-4-carboxamide; trihydrate; hydrochloride. Acotiamide is a new prokinetic agent [1]. It is approved in Japan in 2013 [2]. It causes an increase in the release of acetylcholine thereby it exerts gastroprokinetic activity through acting as an antagonist on the M1 and M2 muscarinic receptors in the enteric nervous system. It inhibits anticholinesterase activity. It may also act directly on the gut and indirectly on the central nervous system by way of brain-gut axis. Studies have shown that acotiamide could enhance gastric emptying and gastric accommodation. Acotiamide could be a promising agent in the treatments with functional dyspepsia $[3,4]$.<smiles>COc1cc(O)c(C(=O)Nc2ncc(C(=O)NCCN(C(C)C)C(C)C)s2)cc1OC</smiles>

Fig. 1: Structure of acotiamide

The presence of impurities can have a significant impact on the product quality, safety and efficacy, hence the percentage level of impurities need to control in the drug substance as well as a drug product. Information on the stability of molecule aids in the selection of proper storage conditions which is the pre-requisite of documentation of drug profile. Force degradation study is an important parameter in pharmaceutical research and development to predict stability of drug. Stress testing helps in identification of degradation products and degradation behaviour of drug $[5,6]$. The literature reveals there were few analytical methods available for determination of acotiamide by HPLC [7], LC-MS-MS [8], UPLC-QTOF-MS $[9,10]$, stability indicating the method by UPLC-Q-TOF-MS (gradient mode) [11], this reported method based on UPLC method.
In the present study, a simple, rapid, precise, isocratic, accurate, cost-effective stability indicating liquid chromatographic method was developed by HPLC for the determination of Acotiamide in tablet dosage forms and validated as per ICH guidelines $[12,13]$.

\section{MATERIALS AND METHODS}

\section{Chemicals, reagents and solutions}

Acotiamide hydrochloride trihydrate (ACOT) bulk drug was provided by Hetero Drugs Pvt. Ltd. Acogut tablets $100 \mathrm{mg}$ were purchased from local pharmacy. HPLC grade methanol and acetonitrile were purchased from Rankem Ltd, Mumbai. HPLC grade triethylamine and formic acid were purchased from Loba Chemie 
Pvt. Ltd, Mumbai. Hydrochloric acid ( $\mathrm{HCl}$ ), sodium hydroxide $(\mathrm{NaOH})$ and hydrogen peroxide $\left(\mathrm{H}_{2} \mathrm{O}_{2}\right)$ were purchased from SD Fine Chem. Ltd. Mumbai, India.

\section{Preparation of mobile phase buffer}

The buffer was prepared by adding $1 \mathrm{ml}$ of triethylamine in $1000 \mathrm{ml}$ of double distilled water and adjusting the $\mathrm{pH}$ with $2 \mathrm{ml}$ of formic acid.

\section{Mobile phase composition}

The mobile phase was prepared using buffer and acetonitrile in the ratio of 70:30. Before use, the mobile phase was filtered through $0.2 \mu$ nylon membrane filter and sonicated for $5 \mathrm{~min}$.

\section{Instrumentation and chromatographic conditions \\ HPLC-PDA}

Analytical Chromatography was performed on Waters Alliance 2695 separation module, Waters 2996 Photo Diode Array Detector (PDA). Data acquisition and integration were performed using Emchem 2 software. Chromatographic separation of ACOT was achieved at column oven temperature of $40{ }^{\circ} \mathrm{C}$ using C-8 Thermo Hypersil BDS column ( $250 \times 4.6 \mathrm{~mm}$ i.d., $5 \mu$ particle size) with mobile phase composition of acetonitrile: $0.1 \%$ triethylamine with $0.2 \%$ formic acid (30:70). The flow rate was at $1.0 \mathrm{ml} \mathrm{min}^{-1}$ and effluent was detected at $282 \mathrm{~nm}$.

\section{Preparation of standard stock solution}

ACOT stock solution $(1000 \mu \mathrm{g} / \mathrm{ml})$ was prepared by dissolving 25 $\mathrm{mg}$ of ACOT in $25 \mathrm{ml}$ of double distilled water and acetonitrile (70:30) in $25 \mathrm{ml}$ of volumetric flask.

\section{Preparation of working standard solution}

ACOT working solution $(100 \mu \mathrm{g} / \mathrm{ml})$ was prepared by transferring $2.5 \mathrm{ml}$ from a stock solution to $25 \mathrm{ml}$ volumetric flask and diluted up to the mark with mobile phase.

\section{Construction of calibration curve}

Aliquots ranging from $0.5 \mathrm{ml}$ to $3.0 \mathrm{ml}$ were taken, from standard stock solution in $10 \mathrm{ml}$ volumetric flask and diluted to $10 \mathrm{ml}$ with mobile phase to give a final concentration of $5,10,15,20,25,30 \mu \mathrm{g}$ $\mathrm{ml}^{-1} . \quad 20 \mu \mathrm{l}$ of each concentration was injected in the chromatographic system and the chromatogram was recorded. A calibration curve was constructed by plotting peak area versus concentration of drug and regression equation was calculated.

\section{Preparation of test sample solution}

20 tablets were crushed using mortar-pestle, the powder was weighed and quantity of powder equivalent to $25 \mathrm{mg}$ of ACOT was transferred in $25 \mathrm{ml}$ volumetric flask, dissolved in a solvent (water: acetonitrile 70:30) and sonicated for $30 \mathrm{~min}$. The solution was filtered through $0.45 \mu$ Nylon 6,6 syringe filter. $2 \mathrm{ml}$ was transferred in $10 \mathrm{ml}$ volumetric flask and volume were adjusted upto the mark with mobile phase to give a concentration of $20 \mu \mathrm{g} / \mathrm{ml}$ of ACOT.

\section{Method validation}

The proposed method was validated according to the ICH guidelines [12] for system suitability, linearity, precision, recovery, limit of detection (LOD) and limit of quantitation (LOQ), robustness, specificity.

\section{System suitability}

System suitability test should be carried out to verify that the analytical system is working properly and can give accurate and precise results. Working standard solutions were prepared and injected six times into the chromatographic system. The system suitability parameters were evaluated for peak area, retention time, tailing factor and theoretical plates of the standard chromatogram.

\section{Linearity and range}

The linearity of the method was evaluated thrice by analyzing the prepared concentration of ACOT in the range of $5-30 \mu \mathrm{g} / \mathrm{ml}$ from the stock solution. $20 \mu \mathrm{l}$ of each solution was injected into HPLC system and the peak area of chromatogram was noted. Linear regression was obtained over the concentration range $(y=m x+c)$.

\section{Precision}

The intra-day precision of the assay method was evaluated at six concentration levels $(5-30 \mu \mathrm{g} / \mathrm{ml})(\mathrm{n}=6)$ against a qualified reference standard. \% RSD of the three obtained assay values at six different concentration levels was calculated. The inter-day precision study was performed in three different days at six different concentration levels $(5-30 \mu \mathrm{g} / \mathrm{ml})$ and each value is the average of the three determinations $(n=3)$. The $\%$ RSD of the three obtained assay values on three different days was calculated.

\section{Accuracy}

The $\%$ recovery was performed by standard addition method. In this method, fixed amount of sample solution of ACOT and increasing amount of its working standard solutions were added at 80,100 and $120 \%$ level of pure drug solution. Standard addition and recovery experiments were conducted to determine the accuracy of the method for the quantitation of ACOT in the drug product.

\section{Limit of detection and limit of quantification (LOQ)}

The limit of detection (LOD) and limit of quantification (LOQ) were calculated by the following formula:

Limit of detection $=3.3^{*} \sigma / \mathrm{S}$

Limit of quantification $=10 * \sigma / \mathrm{S}$

Where $\sigma$ is the standard deviation of $y$-intercept and $S$ is the slope of the calibration curve

\section{Robustness}

The robustness of the assay method was calculated by introducing small changes in the HPLC condition which included $\mathrm{pH}$ of the buffer $(2.8,3.2)$, flow rate $(0.9$ and $1.1 \mathrm{ml} / \mathrm{min})$, the percentage of acetonitrile in the mobile phase (28 and 32). Robustness of the method was studied using three replicates at a concentration level of $15 \mu \mathrm{g} / \mathrm{ml}$ of ACOT.

\section{Specificity}

Specificity is the ability of the method to measure an analyte in presence of its degradation products. ACOT was subjected to various stress conditions like hydrolytic, oxidative, thermal and photolytic. Degraded samples were injected into HPLC system and developed chromatograms were observed for resolution of degraded products.

\section{Force degradation study [14-16]}

A stock solution of ACOT was prepared by dissolving $25 \mathrm{mg}$ of ACOT in $25 \mathrm{ml}$ of double distilled water. This stock solution was used for degradation studies.

\section{Hydrolytic conditions}

\section{Acid degradation}

$5 \mathrm{ml}$ of stock solution of ACOT was taken in $25 \mathrm{ml}$ of volumetric flask, $1 \mathrm{ml}$ of $1 \mathrm{~N} \mathrm{HCl}$ was added and the solution was heated in a water bath at $100{ }^{\circ} \mathrm{C}$ for $3 \mathrm{~h}$. The solution was cooled and neutralized with $1 \mathrm{~N} \mathrm{NaOH}$. Volume was made up to $25 \mathrm{ml}$ with water to make the concentration of $200 \mu \mathrm{g} / \mathrm{ml}$. The solution was filtered through $0.45 \mu$ Nylon 6,6 membrane syringe filter.

\section{Base degradation}

$5 \mathrm{ml}$ of stock solution of ACOT was taken in $25 \mathrm{ml}$ of volumetric flask, $1 \mathrm{ml}$ of $0.5 \mathrm{~N} \mathrm{NaOH}$ was added and the solution was heated in a water bath at $100{ }^{\circ} \mathrm{C}$ for $3 \mathrm{~h}$. The solution was cooled and neutralized with $0.5 \mathrm{~N} \mathrm{HCl}$. Volume was made up to $25 \mathrm{ml}$ with water to make the concentration of $200 \mu \mathrm{g} / \mathrm{ml}$. The solution was filtered through $0.45 \mu$ Nylon 6,6 membrane syringe filter.

\section{Water degradation}

$5 \mathrm{ml}$ of stock solution of ACOT was taken in $25 \mathrm{ml}$ of volumetric flask, $1 \mathrm{ml}$ of water was added and the solution was heated in a 
water bath at $100{ }^{\circ} \mathrm{C}$ for $6 \mathrm{~h}$. The solution was cooled. Volume was made upto $25 \mathrm{ml}$ with water to make the concentration of $200 \mu \mathrm{g} / \mathrm{ml}$. The solution was filtered through $0.45 \mu$ membrane syringe filter

\section{Oxidizing conditions}

Hydrogen peroxide-induced degradation $5 \mathrm{ml}$ of stock solution of ACOT was taken in $25 \mathrm{ml}$ of volumetric flask, $1 \mathrm{ml}$ of $6 \%$ hydrogen peroxide was added. The solution was kept at room temperature for $48 \mathrm{~h}$. The solution was made upto volume with water. The solution was filtered through $0.45 \mu$ Nylon 6,6 membrane syringe filter.

\section{Thermal conditions}

Dry heat $25 \mathrm{mg}$ of ACOT was placed in an oven at $80^{\circ} \mathrm{C}$ for $8 \mathrm{~d}$ under dry heat condition in the dark and then cooled to room temperature. Volume was made with water to get a concentration of $200 \mu \mathrm{g} / \mathrm{ml}$.

\section{Photolytic degradation}

For the photochemical study, ACOT equivalent to $25 \mathrm{mg}$ was spread in $1 \mathrm{~mm}$ thickness on a petridish and exposed to 5383 LUX and 144 $\mathrm{UV} / \mathrm{cm} 2$ for $8 \mathrm{~d}$ and volume was made up to $25 \mathrm{ml}$ with water. $5 \mathrm{ml}$ of the solution was taken and further diluted upto $25 \mathrm{ml}$ with water to make the concentration of $200 \mu \mathrm{g} / \mathrm{ml}$.

Table 1: Stress conditions for forced degradation study of ACOT

\begin{tabular}{lll}
\hline Stress condition & Solvent & Temperature \\
\hline Hydrolytic & & Time \\
Acid & $1 \mathrm{~N} \mathrm{HCl}$ & $100^{\circ} \mathrm{C}$ \\
Base & $0.5 \mathrm{~N} \mathrm{NaOH}$ & $100^{\circ} \mathrm{C}$ \\
Neutral & Water & $100^{\circ} \mathrm{C}$ \\
Oxidative & $6 \% \mathrm{H}_{2} \mathrm{O}_{2}$ & $\mathrm{~h}$ \\
Thermal & & $6 \mathrm{~h}$ \\
Dry Heat & --- & $48 \mathrm{~h}$ \\
Photolytic & --- & $80^{\circ} \mathrm{C}$ \\
\hline
\end{tabular}

\section{RESULTS}

\section{Method development and optimization}

A detection wavelength $282 \mathrm{~nm}$ was selected from the range UV spectral data due to its high sensitivity for all degradation products and minimal difference in response factors. ACOT having pKa 10.24, $\mathrm{pH} 3.0$ buffer was selected to enable better column performance. Isocratic run was accessed using mobile phase $0.1 \%$ triethylamine adjusted to $\mathrm{pH} 3$ with $0.2 \%$ formic acid and acetonitrile (70:30) on C-8 and C-18 column. Column C-8 with column oven temperature of $40{ }^{\circ} \mathrm{C}$ provided the highest number of peaks and better resolution. Thus, further experiments were carried out using thermo hypersil BDS C8 column.

\section{Method validation}

\section{System suitability method}

The developed method has produced theoretical plates more than 2000 with tailing factor less than 2 . The \% RSD of peak area was less than 2 which ensured the suitability of the developed method. The results of the system suitability study are summarised in table 2 .

Table 2: System suitability parameters of ACOT

\begin{tabular}{ll}
\hline Parameters & mean \pm SD \\
\hline Retention Time & $9.387 \pm 0.057$ \\
Theoretical Plates & $12098 \pm 21.36$ \\
Tailing factor & $1.047 \pm 0.043$ \\
Peak Area & $762504 \pm 0.495$ \\
\hline
\end{tabular}

\section{Linearity and range}

In the proposed validation method, the retention time of ACOT was $9.3 \mathrm{~min}$. The calibration curve for ACOT was constructed by plotting area versus their corresponding concentrations, linearity was found over the range $5-30 \mu \mathrm{g} / \mathrm{ml}$ with a coefficient of relation $\left(R^{2}\right)$. Results of linearity are shown in fig. 2 and table 3 .

\section{Detection and quantification limits}

According to the pharmaceutical recommendations, limit of detection (LOD) and limit of quantification (LOQ) were determined, at the signal to noise ratios of 3:1 and 10:1, respectively. Limit of detection of ACOT was found to be $0.36 \mu \mathrm{g} / \mathrm{ml}$. Limit of quantification of ACOT was found to be $1.10 \mu \mathrm{g} / \mathrm{ml}$.

Table 3: Calibration curve of ACOT

\begin{tabular}{lll}
\hline Level & Concentration $(\boldsymbol{\mu g} / \mathbf{m l})$ & Area \\
\hline 1 & 5 & 150914 \\
2 & 10 & 361779 \\
3 & 15 & 568471 \\
4 & 20 & 771652 \\
5 & 25 & 945829 \\
6 & 30 & 1180668 \\
\hline
\end{tabular}

\section{Precision and accuracy}

The within-day (intra-day) precision and accuracy for the proposed method were studied at three concentration levels of ACOT using three replicate determinations for each concentration within one day. Similarly, the between-day (inter-day) precision and accuracy were tested by analyzing the same three concentrations using three replicate determinations repeated on three days. Recoveries were calculated using the regression equation and they were satisfactory. The percentage of relative standard deviation (\%RSD) was less than $1.5 \%$ providing the high repeatability, intermediate precision and accuracy of the developed method for the estimation of ACOT in bulk form. Results of precision are shown in table 4, 5. Results of recovery are shown in table 6. 


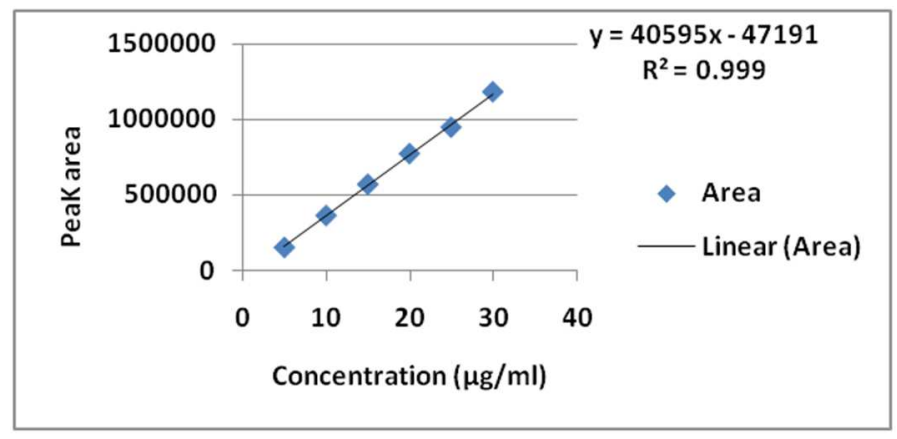

Fig. 2: Calibration curve of ACOT

Table 4: Intra-day precision of ACOT $(n=3)$

\begin{tabular}{llll}
\hline Concentration $(\boldsymbol{\mu g} / \mathbf{m l})$ & Area $(m e a n \pm$ SD) & \%RSD & Retention time (mean \pm SD) \\
\hline 10 & $352540 \pm 4129.327$ & 1.171 & $9.608 \pm 0.085$ \\
20 & $764518.3 \pm 3789.857 \pm$ & 0.495 & $9.644 \pm 0.040$ \\
30 & $1189078 \pm 14035.98$ & 1.180 & $9.652 \pm 0.022$ \\
\hline
\end{tabular}

$\mathrm{n}=$ number of determinations, $\mathrm{SD}=$ Standard Deviation, $\% \mathrm{RSD}=\%$ Relative Standard Deviation

Table 5: Inter-day precision of ACOT $(n=3)$

\begin{tabular}{llll}
\hline Concentration $(\boldsymbol{\mu g} / \mathbf{m l})$ & Area $($ mean \pm SD) & \% RSD & Retention time (mean \pm SD) \\
\hline 10 & $366767 \pm 6371.719$ & 1.737 & $9.613 \pm 0.078$ \\
20 & $772256 \pm 8524.635$ & 1.103 & $9.609 \pm 0.043$ \\
30 & $1200857 \pm 16000.6$ & 1.332 & $9.637 \pm 0.040$ \\
\hline
\end{tabular}

$\mathrm{n}=$ number of determinations, $\mathrm{SD}=$ Standard Deviation, $\%$ RSD $=\%$ Relative Standard Deviation

Table 6: Recovery studies of ACOT $(n=3)$

\begin{tabular}{|c|c|c|c|c|c|c|c|}
\hline $\begin{array}{l}\text { Concentration } \\
(\mu \mathrm{g} / \mathrm{ml})\end{array}$ & $\begin{array}{l}\text { Amt of ACOT added } \\
(\mu \mathrm{g} / \mathrm{ml})\end{array}$ & $\begin{array}{l}\text { Amt of ACOT recovered } \\
(\mu \mathrm{g} / \mathrm{ml})\end{array}$ & mean \pm SD & $\begin{array}{l}\% \\
\text { RSD }\end{array}$ & $\begin{array}{l}\% \\
\text { recovery }\end{array}$ & mean \pm SD & $\begin{array}{l}\% \\
\text { RSD } \\
\end{array}$ \\
\hline 20 & 10 & 9.972 & $9.93 \pm 0.04$ & 0.40 & 99.72 & $99.3 \pm 0.40$ & 0.40 \\
\hline 20 & 20 & 19.938 & $19.8 \pm 0.12$ & 0.63 & 99.69 & $99.3 \pm 0.29$ & 0.29 \\
\hline 20 & 30 & 29.847 & $29.6 \pm 0.15$ & 0.57 & 99.49 & $98.9 \pm 0.51$ & 0.52 \\
\hline
\end{tabular}

$\mathrm{n}=$ number of determinations, $\mathrm{SD}=$ Standard Deviation, $\% \mathrm{RSD}=\%$ Relative Standard Deviation

\section{Robustness}

The robustness was examined by evaluating the influence of small variations in different conditions such as flow rate, detection wavelength and organic ratio. The average value of $\%$ RSD for determination of ACOT less than 2\% revealed robustness of the method. Results of robustness studies are shown in table 7.

Table 7: Robustness studies of ACOT $(n=3)$

\begin{tabular}{llll}
\hline Flow rate & Area (mean \pm SD) & \% RSD & Retention time (mean \pm SD) \\
0.9 & $571144.3 \pm 7238.28$ & 1.267 & $11.39333 \pm 0.06$ \\
1 & $570358.3 \pm 8351.74$ & 1.464 & $9.606333 \pm 0.02$ \\
1.1 & $573424.3 \pm 7510.62$ & 1.309 & $8.342667 \pm 0.02$ \\
Organic ratio acetonitrile & Area (mean \pm SD) & \%RSD & Retention Time (mean \pm SD) \\
28 & $577713.7 \pm 4829.15$ & 0.835 & $11.41633 \pm 0.10$ \\
30 & $578040.3 \pm 5985.97$ & 1.035 & $9.631667 \pm 0.01$ \\
32 & $567522.3 \pm 5833.48$ & 1.027 & $8.592333 \pm 0.07$ \\
Wavelength & Area (mean \pm SD) & $\%$ RSD & Retention Time (mean \pm SD) \\
281 & $578040.3 \pm 7076.25$ & 1.224 & $9.521 \pm 0.008$ \\
282 & $581313.7 \pm 7879.20$ & 1.355 & $9.505 \pm 0.072$ \\
283 & $568682 \pm 5850.65$ & 1.028 & $9.510 \pm 0.017$ \\
\hline
\end{tabular}

$\mathrm{n}=$ number of determinations, $\mathrm{SD}=$ Standard Deviation, \%RSD = \% Relative Standard Deviation

\section{Stability of solutions}

Solutions containing different concentrations of ACOT were prepared from standard solution and stored at room temperature for $24 \mathrm{~h}$. They were then injected into LC system. No additional peaks were found in chromatogram and area under the peak comes within $2 \%$.

\section{Filter compatibility}

Filter compatibility was performed on $0.45 \mu$ Nylon 6,6 syringe filter, $0.45 \mu$ PTFE hydrophilic syringe filter and $0.45 \mu$ PTFE hydrophobic syringe filter. Filter compatibility study was done by $\%$ recovery method. The sample was filtered through syringe filters 
and percentage assay was calculated and variation in the assay value was compared against the centrifuged sample. Results are shown in table 8. After analysis, it was found that Nylon 6,6 syringe filter and PTFE hydrophilic syringe filter were suitable for filtration.

Table 8: Filter compatibility study

\begin{tabular}{lcc}
\hline Sample name & Peak area & \% difference \\
\hline Standard sample & 771427 \\
Sample filtered through $0.45 \mu$ Nylon 6,6 syringe filter & 770936 \\
Sample filtered through $0.45 \mu$ PTFE hydrophilic syringe filter & 768234 \\
Sample filtered through $0.45 \mu$ PTFE hydrophobic syringe filter & 0.2 \\
\hline
\end{tabular}

\section{Force degradation study}

The results from the stress testing studies indicate that the method is highly specific for ACOT. Degradation products were completely distinguishable from the parent compound. The drug undergoes significant degradation under acid, alkaline conditions. Alkaline degradation was faster than acidic degradation. The drug was relatively stable in oxidative neutral, dry heat and photolytic degradation. Three degradation products were obtained in alkaline hydrolysis. In alkaline hydrolysis, degradation peaks were obtained at RT of 3.7, 4.5 and $6.8 \mathrm{~min}$ on heating. One degradation product was obtained in acid hydrolysis at RT of 5.3 min. The typical chromatogram of ACOT and stressed samples are shown in fig. 3-10.

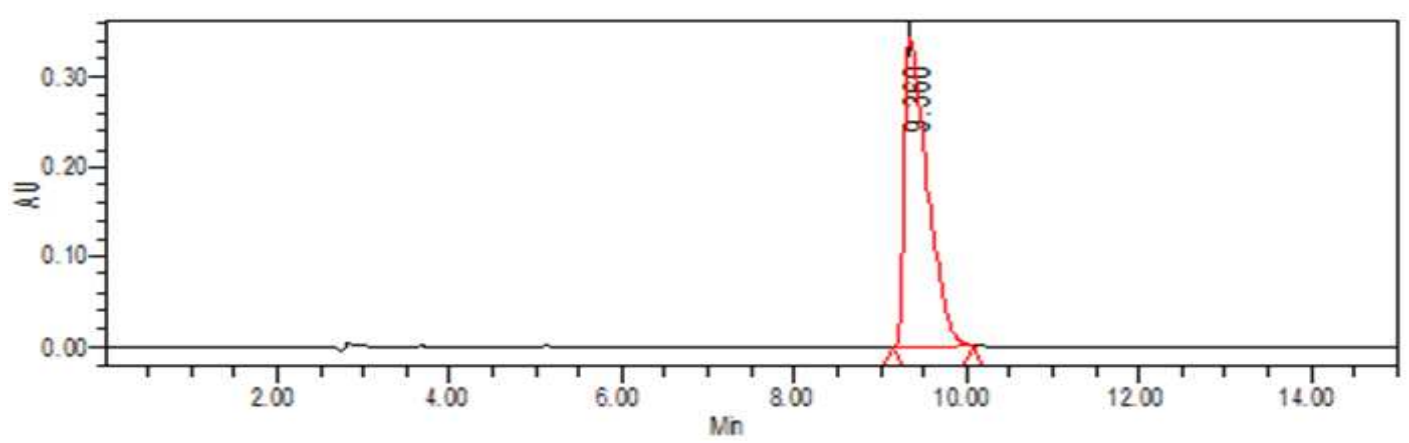

Fig. 3: Chromatogram of ACOT (200 ppm)

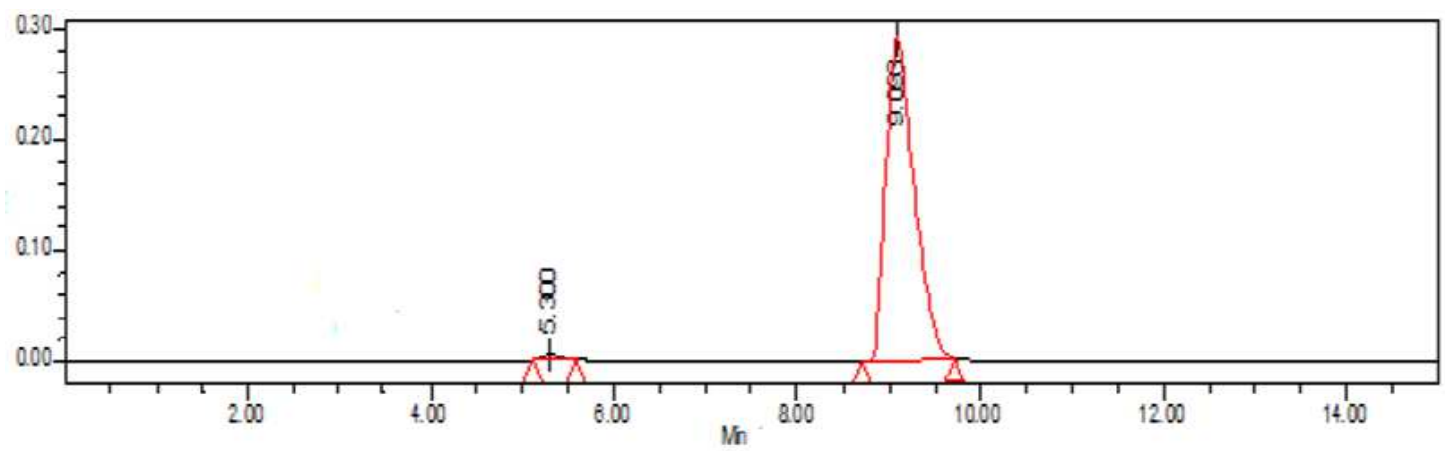

Fig. 4: Degradation of ACOT in $1 \mathrm{~N} \mathrm{HCl}$ at $100^{\circ} \mathrm{C}$ for $3 \mathrm{~h}$

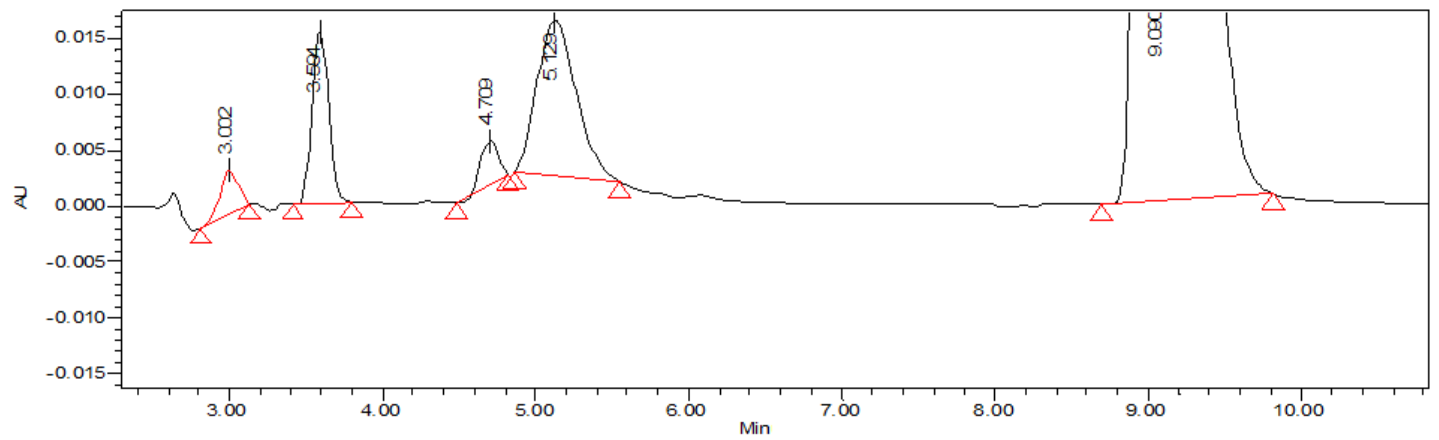

Fig. 5: Degradation of ACOT in $0.5 \mathrm{M} \mathrm{NaOH}$ at $100^{\circ} \mathrm{C}$ for $3 \mathrm{~h}$ (Zoomed view) 


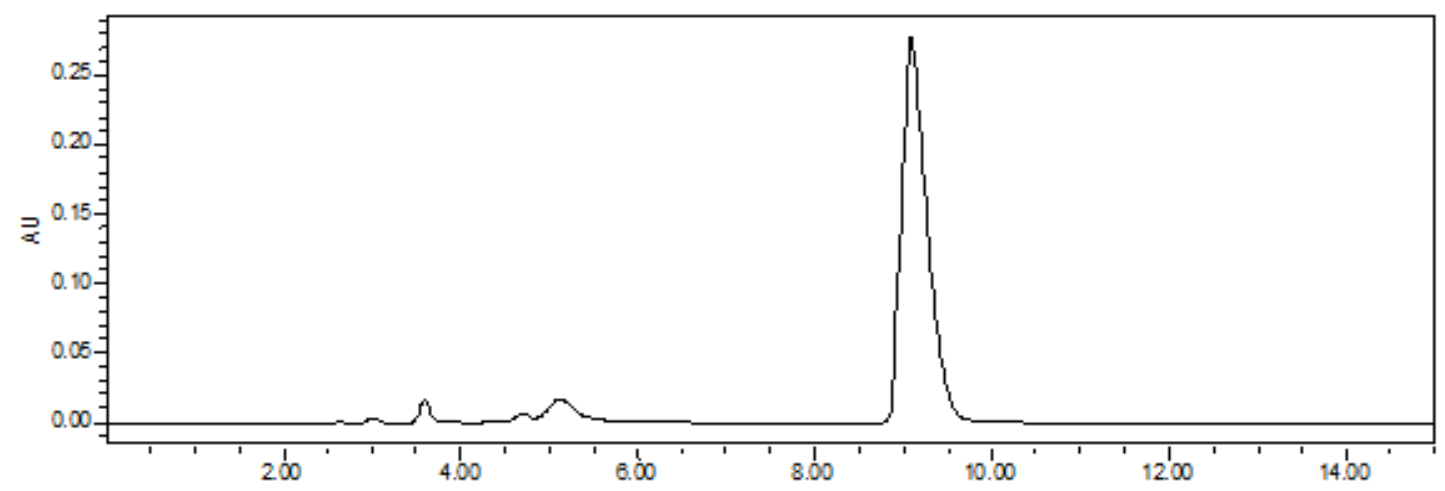

Fig. 6: Degradation of ACOT in $0.5 \mathrm{M} \mathrm{NaOH}$ at $100^{\circ} \mathrm{C}$ for $3 \mathrm{~h}$ (Full view)

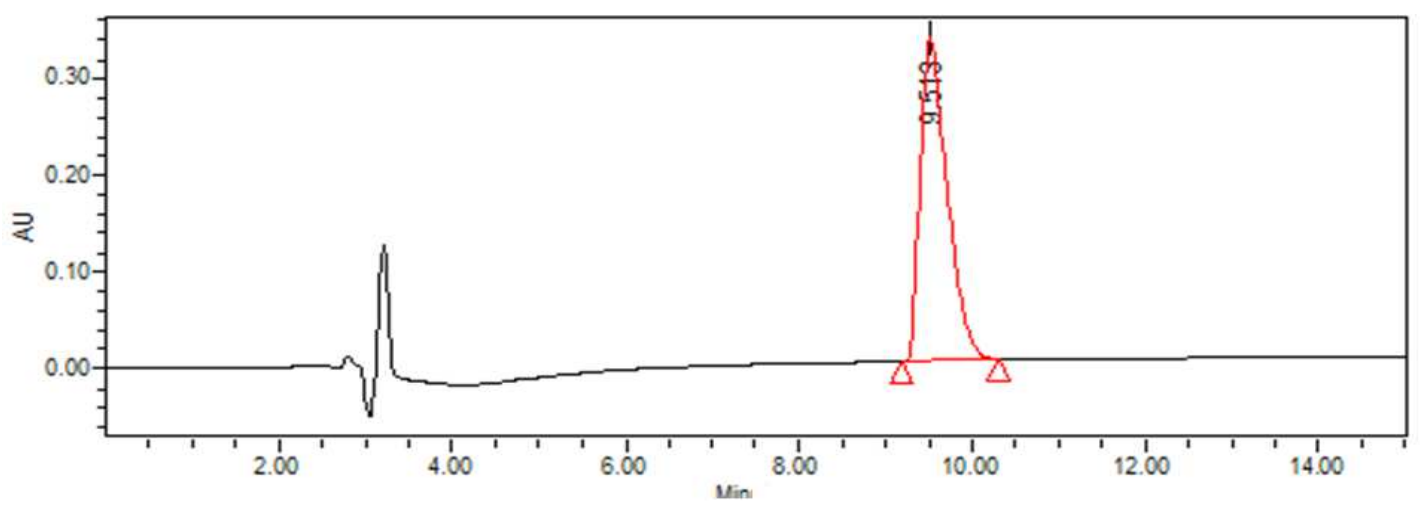

Fig. 7: Degradation of ACOT in $6 \% \mathrm{H}_{2} \mathrm{O}_{2}$ at room temperature for $48 \mathrm{~h}$

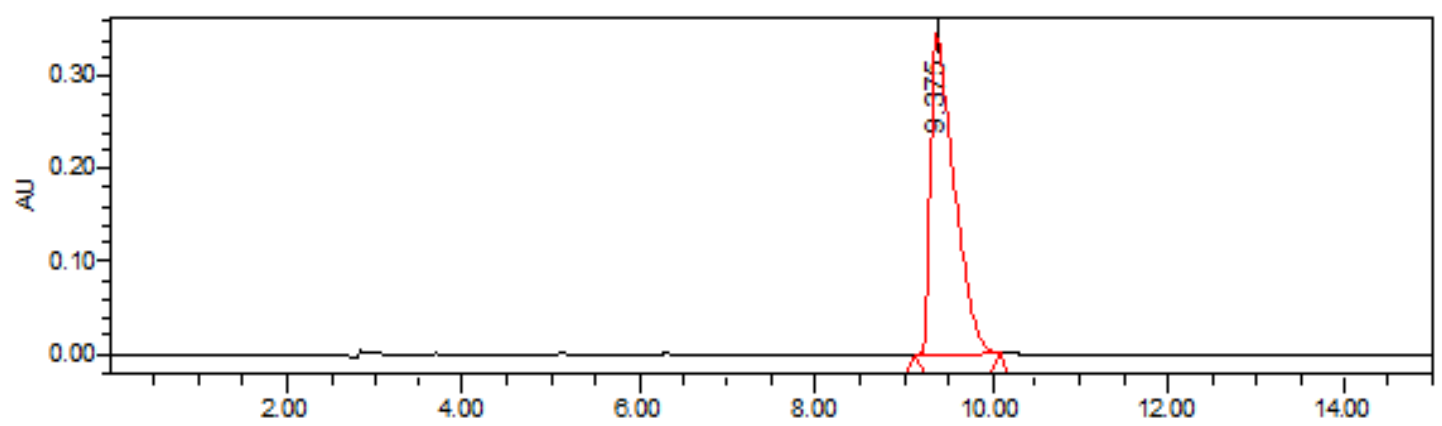

Fig. 8: Degradation of ACOT in thermal at $80^{\circ} \mathrm{c}$ for $8 \mathrm{~d}$

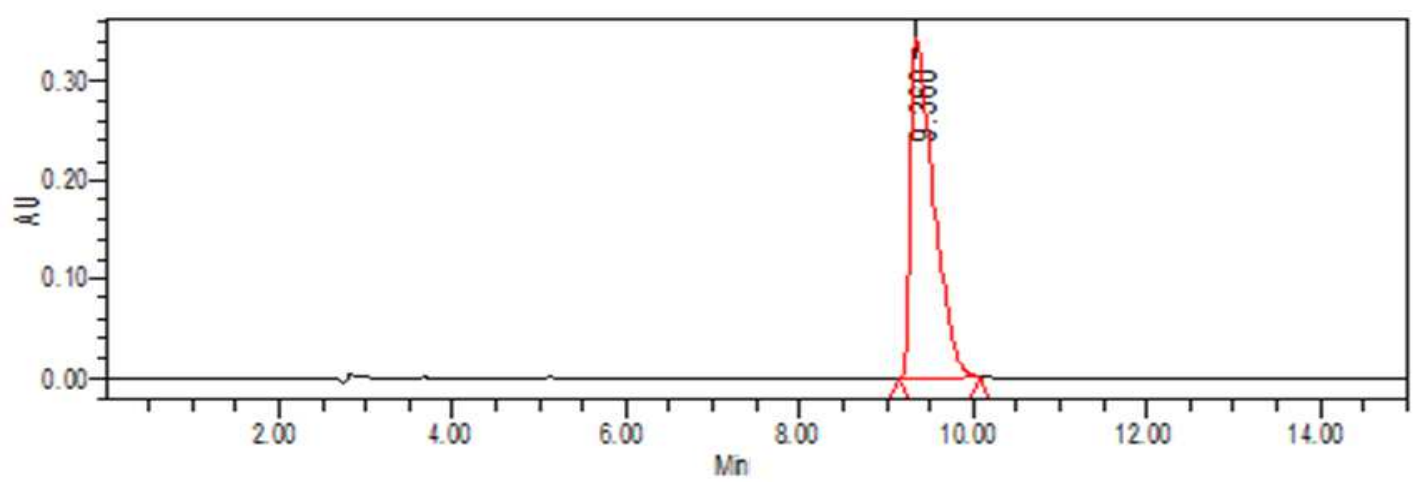

Fig. 9: Degradation of ACOT in photolytic condition dry for $11 \mathrm{~d}$ 


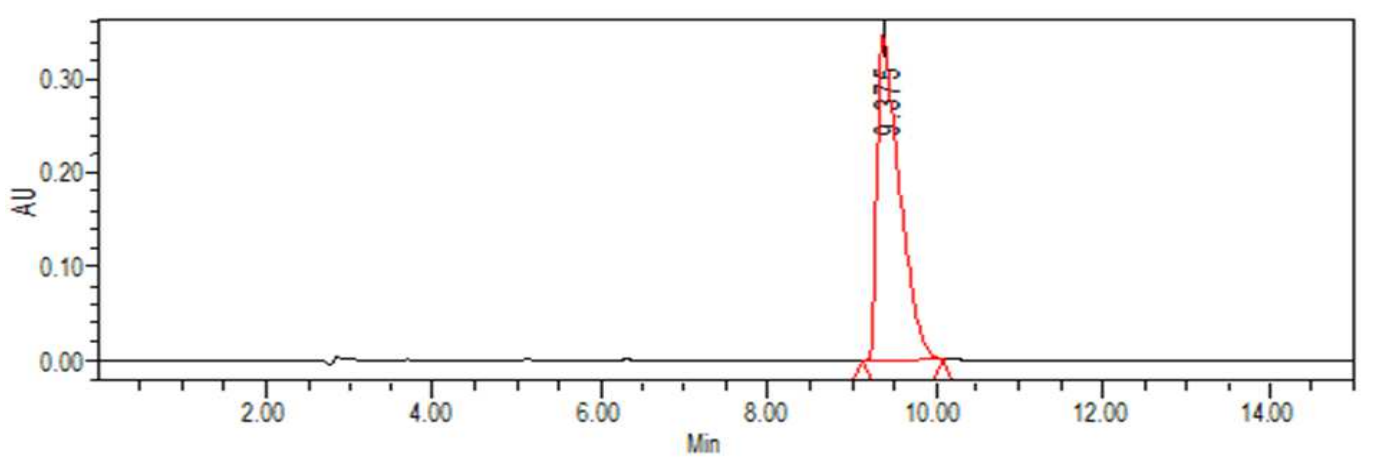

Fig. 10: Degradation of ACOT in photolytic solution for $11 \mathrm{~d}$

Table 9: Data of forced degradation studies of ACOT

\begin{tabular}{|c|c|c|c|c|c|c|c|}
\hline Conditions & & $\begin{array}{l}\text { \% degradation } \\
\text { in API }\end{array}$ & $\%$ API & $\begin{array}{l}\text { \% degradation in } \\
\text { formulation }\end{array}$ & $\begin{array}{l}\text { \% API in } \\
\text { formulation }\end{array}$ & $\begin{array}{l}\text { No. of } \\
\text { degradation } \\
\text { products }\end{array}$ & $\begin{array}{l}\text { RT of } \\
\text { degradation } \\
\text { products }\end{array}$ \\
\hline Acidic & $\begin{array}{l}1 \mathrm{~N} \mathrm{HCl} \text { at } 100 \\
{ }^{\circ} \mathrm{C} \text { for } 3 \mathrm{~h}\end{array}$ & $0.96 \%$ & $99.3 \%$ & $0.7 \%$ & $99.3 \%$ & 1 & 5.300 \\
\hline Alkaline & $\begin{array}{l}0.5 \mathrm{~N} \mathrm{NaOH} \text { at } \\
100^{\circ} \mathrm{C} \text { for } 3 \mathrm{~h}\end{array}$ & $15.2 \%$ & $84.7 \%$ & $14.7 \%$ & $85.3 \%$ & 3 & $\begin{array}{l}3.591 \\
4.709 \\
5.129\end{array}$ \\
\hline Oxidation & $\begin{array}{l}6 \% \mathrm{H}_{2} \mathrm{O}_{2} \text { for } 48 \\
\mathrm{~h} \text { at RT }\end{array}$ & No degradation & $\begin{array}{l}99.2 \\
\%\end{array}$ & No degradation & $99.5 \%$ & - & - \\
\hline \multirow[t]{2}{*}{ Thermal } & $\begin{array}{l}\text { Dry at } 80^{\circ} \mathrm{C} \text { for } \\
8 \mathrm{~d}\end{array}$ & No degradation & $99.8 \%$ & No degradation & $99.7 \%$ & - & - \\
\hline & $\begin{array}{l}\text { Solution at } 80 \\
{ }^{\circ} \mathrm{C} \text { for } 8 \mathrm{~d}\end{array}$ & No degradation & $\begin{array}{l}99.5 \\
\%\end{array}$ & No degradation & $99.7 \%$ & - & - \\
\hline \multirow[t]{2}{*}{ Photolytic } & Dry for $11 \mathrm{~d}$ & No degradation & $\begin{array}{l}99.5 \\
\%\end{array}$ & No degradation & $99.8 \%$ & - & - \\
\hline & $\begin{array}{l}\text { Solution for } 11 \\
\text { d }\end{array}$ & No degradation & $\begin{array}{l}99.7 \\
\%\end{array}$ & No degradation & $99.8 \%$ & - & - \\
\hline
\end{tabular}

\section{DISCUSSION}

The ICH Q1A [13] guideline suggests that stability indicating method must be performed to monitor the properties of drug substance which are likely to change during storage and which are likely to affect quality, the efficacy of the formulation.

During development of stability indicating method, in alkaline degradation conditions for separation of degradation products from ACOT, trials were taken with mobile phase $0.1 \%$ formic acid: methanol, $0.1 \%$ formic acid: acetonitrile on C-18 column and C-8 column. Degradation peaks were resolved from ACOT on C-8 column with column oven temperature of $40{ }^{\circ} \mathrm{C}$ with a mobile phase of $0.1 \%$ triethylamine in $0.2 \%$ formic acid: acetonitrile in the ratio of 70:30. The retention time of ACOT was 9.387 min. Detection was done at $282 \mathrm{~nm}$. The method was validated according to ICH guidelines. The linearity of ACOT was found to be in the range of $5-30 \mu \mathrm{g} / \mathrm{ml}$ with a correlation coefficient of 0.999 .\% Recovery was found to be 98.9 $99.3 \%$. Significant degradation was observed in alkaline conditions with three degradation products and in acidic conditions, one degradation product is formed. The reported method [11] is developed on UPLC, with cyano column. Those facilities as UPLC instrument and cyano column both are rarely available in University or institute. The degradation conditions in the reported methods are harsh conditions. Our method is developed by HPLC method on C-8 column. The developed method is simple, precise, isocratic, accurate, robust, cost-effective and with available facilities in common laboratories in absence of advanced facilities and instrument.

\section{CONCLUSION}

A simple, specific, accurate, precise stability indicating method has developed. The proposed method presented the ability to separate ACOT from all its degradation products and therefore can be applied instability testing of the commercially available formulation.

\section{ACKNOWLEDGEMENT}

The authors would like to thank Hetero Drugs Pvt. Ltd(Hyderabad, India) for providing Acotiamide (gift sample).

\section{AUTHORS CONTRIBUTIONS}

All authors have contributed equally to the manuscript.

\section{CONFLICTS OF INTERESTS}

Authors declare no conflicts of interest

\section{REFERENCES}

1. Altan E, Masaoka T, Faree R, Track J. Acotiamide, a novel gastroprokinetic for the treatment of patients with functional dyspepsia: postprandial distress syndrome. Expert Rev Gastroenterol Hepatol 2012;6 Suppl 5:533-44.

2. Nolan ML, Scott LJ. Acotiamide, first global approval. Drugs 2013;73 Suppl 12:1377-83.

3. Mayanagi S, Kishino M, Kitagawa Y, Sunamor M. Efficacy of acotiamide in combination with esomeprazole for functional dyspepsia refractory to proton pump inhibitors. Tohuku J Exp Med 2014;234 Suppl 3:237-40.

4. Fu K, Yang L, Wang Q, Zhan F, Wang B, Yang Q, et al. A three step synthesis of acotiamide for the treatments of patients with functional dyspepsia. Org Proc Res Dev 2015;19:2006-11.

5. Bakshi M, Singh S. Development of validated stabilityindicating method-critical review. J Pharm Biomed Anal 2002;28:1011-40.

6. Bakshi M, Singh S. Guidance on the conduct of stress testing to determine the inherent stability of drugs. Pharma Tech On-line; 2000. p. 1-14.

7. Vani R, Sunitha M. Analytical method development and validation for the determination of acotiamide hydrochloride 
using reverse phase HPLC method in bulk and tablet. World J Pharm Pharma Sci 2017;6 Suppl 10:768-75.

8. Jing L, Rui $\mathrm{H}$, Zhi W, Haijun Q, Majuan S, Zhenhuan Z. Development and validation of sensitive and specific LC-MS-MS method for the determination of acotiamide in rat plasma. J Chromatogr Sci 2016;54 Suppl 6:1004-9.

9. Patel PN, Kalariya PD, Swamy CV, Gananadhamu S, Srinivas R. Quantitation of acotiamide in rat plasma by UHPLC-Q-TOF-MS: method development. Validation Appl Pharmacokinetics 2016;30:363-8.

10. Patel PN, Kalariya PD, Thummar M, Gananadhamu S, Srinivas R. In vivo metabolite identification of acotiamide in rats using ultra-performance liquid chromatography-quadrupole/timeof-flight mass spectrometry: characterization of in vivo metabolites of acotiamide in rats by LC-MS. Biomed Chromatogr 2017:31:3915.

11. Thummar M, Patel PN, Samanthula G, Ragampeta S. Stabilityindicating assay method for acotiamide: Separation, identification and characterization of its hydroxylated and hydrolytic degradation products along with a process-related impurity by ultra-high-performance liquid chromatography/ electrospray ionization quadrupole time-of-flight tandem mass spectrometry. Rapid Commun Mass Spectrom 2017;31 Suppl 21:1813-24.

12. ICH. Validation of analytical procedures: Text and Methodology Q2 (R1), International Conference on Harmonization; 2005.

13. ICH. Stability testing of new drug substances and products Q1A (R2), International Conference on Harmonization; 2003.

14. Gupta VK, Chaturvedi V. A study on forced degradation and validation of stability indicating an RP-HPLC method for determination of bezalkonium chloride in the azelastine hydrochloride pharmaceutical ophthalmic formulation. Asian J Pharm Clin Res 2017;10 Suppl 11:374-82.

15. Chakravarthy AV, Sailaja BBV, Praveen KA. Stability indicating a reverse high-performance liquid chromatographic method for simultaneous estimation of labetalol and its degradation products in tablet dosage forms. Asian J Pharm Clin Res 2016;9 Suppl 2:242-9.

16. Athavia BA, Dedania ZR, Dedania RR, Vijayendra Swamy SM, Prajapati CB. Stability indicating HPLC method for determination of vilazodone hydrochloride. Int J Curr Pharm Res 2017;9 Suppl 4:123-9. 